\title{
Mariologiczna interpretacja perykopy Jezus w Nazarecie (Mt 13, 53-58)
}

Należy uznać, że problematyka Mt 13 jest bardzo złożona. Rozdział ten w Mateuszowej Ewangelii zawiera trzecią z kolei mowę Jezusa, która przez uczonych jest inaczej nazywana księgą przypowieści. W Mt 11-12 Ewangelista zawarł opisy uzdrowień, dyskusji i ostrych polemik; rozdziały te nazywane są sekcją czynów Jezusa. Ukazują one, że osoba Jezusa i Jego misja podzieliły ludzi na dwie grupy. Jedną z nich stanowią zwolennicy głoszonego przez Jezusa królestwa Bożego, którzy z wiarą je przyjęli. Drugi obóz stanowiła grupa oficjalnych religijnych przywódców ludu, która nie uwierzyła w posłannictwo Jezusa Chrystusa, a co za tym idzie również nie przyjęła Jezusowej nauki wypływającej z głoszonej przez Niego Dobrej Nowiny w Jego verba et gesta. Reszta ludu obserwowała działalność publiczną Jezusa z wielkim zdumieniem, nawet zachwytem, w sercu poszukując odpowiedzi na pytanie: czy Jezus nie jest przypadkiem Synem Dawida? ${ }^{1}$ Jednakże nie opowiedzieli się oni ani za Jezusem, ani przeciw Niemu². Zawarte w Mt 13 przypowieści z jednej strony usiłują wyjaśnić, dlaczego głoszone przez Jezusa królestwo Boże nie potrzebuje spektakularnej potęgi, świetności i chwały doczesnej, z drugiej zaś jakby w sposób zamierzony zdają się utwierdzać w przekonaniu, że głoszone przez Jezusa królestwo Boże jest, po ludzku sądząc, (rzekomo) słabe, niepozorne, maleńkie i nie bardzo można na nim polegać3.

\footnotetext{
${ }^{1}$ Por. Mt 12, 23.

${ }^{2}$ Por. J. Dupont, Le point de vue de Matthieu dans le chaptire des paraboles, [w:] L'evangile selon Matthieu, red. M. Didier, Grmbloux 1972, s. 221-259.

${ }^{3}$ Por. J. Homerski, Ewangelia wedtug św. Mateusza. Wstęp - Przekład z oryginalu - Komentarz, s. 214; por. również: B. Gerhardsson, The seven Paraboles in Matthew XIII, [w:] Supplements to Novum Testamentum, nr 19, Leiden 1972, s. 16-37; E. Schweizer, Zur Sondertradition der Gleichnisse bei Matthäus, [w:] Tradition und Glaube. Festgabe für K. G. Kuhn, red. G. Jeremias, Göttingen 1972, s. 277-282.
} 


\section{Analiza egzegetyczna tekstu (Mt 13, 53-58)}

Przekaz ewangeliczny umieszczony w Mt 13,53-58 i relacjonujący pobyt Jezusa w Nazarecie można inaczej nazwać przekazem o odrzuceniu Jezusa w Jego mieście rodzinnym ${ }^{4}$. Św. Mateusz, redagując ową perykopę, przejął ją ze swojego źródła, a mianowicie z Ewangelii według św. Marka ${ }^{5}$. Jednakże autor pierwszej Ewangelii synoptycznej - perykopę tę nieco odmiennie, niż św. Marek redaguje - porządkuje.

W Ewangelii według św. Marka relacja ta $(6,1-6)$ jest umieszczona pomiędzy dwoma blokami ${ }^{6}: \mathrm{z}$ jednej strony jest sumarium o cudach $5,1-43$, z drugiej strony - opis o rozesłaniu uczniów 6, 6b-13.

Natomiast w Ewangelii według św. Mateusza zostaje umieszczona z jednej strony pomiędzy nauczaniem Jezusa w przypowieściach (Mt 13, 1-52), z drugiej strony pomiędzy relacją o pojmaniu i śmierci Jana Chrzciciela (Mt 14, 1-12).

W dotychczasowym dorobku biblijnym na temat Mt 13, 53-58 brane jest jeszcze pod uwagę inne uporządkowanie, czy jakkolwiek nazwiemy umieszczenie w kolejności tejże perykopy. Uważa się bowiem, że św. Mateusz, umieszczając opis o pobycie Jezusa w Nazarecie bezpośrednio po nauczaniu w przypowieściach (Mt 13, 1-52) ${ }^{7}$, zakłada tym samym o wiele intensywniejsze głoszenie królestwa Bożego, niż św. Marek w swojej relacji (Mk 6, 1-6). Dzięki temu ukazuje, że poddana analizie perykopa Mt 13, 53-58 zawiera sama w sobie duży ciężar znaczeniowy. Przecież już w ramach nauczania Jezusa w przypowieściach dochodzi do głosu echo rozdźwięku następującego przez Jezusowe zwiastowanie powszechnego Bożego panowania. Zauważalna jest szczególna wrogość wobec Chrystusa u niewierzących w Jego nauczanie i posłannictwo zbawcze. Ujawnia się ich zatwardziałość serc ${ }^{8}$.

Św. Mateusz, umieszczając relację 13, 53-58 przed perykopą opisującą ścięcie Jana Chrzciciela (Mt 14, 1-12), wyraził tym samym zamiar wyakcentowania, a zarazem wyjaśnienia, że los Jana Chrzciciela jest odzwierciedleniem, zapowiedzią męki i śmierci Jezusa Chrystusa. Zarówno bowiem Jan Chrzciciel, jak i Jezus Chrystus zostali odrzuceni i skazani na śmierć, więc zaznali końca swej misji typowego dla proroków9.

Św. Mateusz inaczej uporządkował perykopę $(13,53-58)$ oraz dokonał kilku zmian w samym pierwowzorze tekstu źródłowego Ewangelii według św. Marka.

${ }^{4}$ Por. Mk 6, 1-6; Łk 4, 16-30.

${ }^{5}$ Por. Mk 6, 1-6; por. J. Homerski, Ewangelia wedtug św. Mateusza ..., s. 214; por. również w ogólności J. Dupont, Porquoi des paraboles? La methode parabolique de Jesus, [w:] Lire la Bible, nr 46, Paris 1977.

${ }^{6}$ Por. K. Berger, Materialien zu Form und Überlieferungsgeschichte neutestamentlicher Gleichnisse, [w:] Novum Testamentum, nr 15, Leiden 1973, s. 1-37.

${ }^{7} \mathrm{~W}$ chronologicznej kolejności relacji ewangelicznej, trzeciej wielkiej kompozycji retorycznej (Mt 13, 1-52), po Kazaniu na górze (Mt 5-7) i mowie przy rozesłaniu uczniów (Mt 9, 35-11, 1).

${ }^{8}$ Por. Mt 13, 14. Św. Mateusz w relacji 13, 53-58 pragnie jak najdosadniej odnieść się krytycznie do tego, co zostało uprzednio powiedziane w Mt 13, 14n; por. również Iz 6, 9n (LXX).

9 Por. W. Harnisch, Die Sprachkraft der Analogie. Zur These vom ,argumentativen Charakter" der Gleichnisse Jesu, „Studia Theologica” 28 : 1974, s. 1-20. 
Owe zmiany można sklasyfikować w dwóch grupach, a mianowicie jako: mniej i bardziej ważne dla naszej tematyki mariologicznej.

Najpierw przedstawimy owe mniej ważne zmiany dokonane przez Ewangelistę w relacji Mt 13, 53-58 - względem Markowego tekstu źródłowego (6, 1-6):

- św. Mateusz nie wspomina o uczniach towarzyszących Jezusowi ${ }^{10}$, na co wskazuje fakt zmiany kontekstu relacji - Mt 13, 53-58.

- św. Mateusz wyakcentował, że Jezus nauczał ,ich w synagodze” (Mt 13, 54). Ów leksem ukazuje pewien dystans, na który zdaje się w swoim zamiarze redakcyjnym zwracać uwagę autor pierwszej Ewangelii synoptycznej ${ }^{11}$.

- św. Mateusz, nie zawarł w swojej relacji Markowego leksemu: „zaczął nauczać w synagodze" (Mk 6,2), lecz umieścił w zamian wskazówkę, aby dać wyraz akceptacji i większej bezpośredniości dla przesłania Dobrej Nowiny Jezusa Chrystusa, skierowanej w tym momencie do mieszkańców Nazaretu: „nauczał w ich synagodze" (Mt 13, 54).

- św. Mateusz nadaje niejako mniejszy ciężar znaczeniowy spostrzeżeniu św. Marka: „I nie mógł tam zdziałać żadnego cudu [...]” (Mk 6, 5a), dzięki stwierdzeniu rzeczywistości w sposób bardziej realny i dosadny: „I niewiele zdziałał tam cudów" (Mt 13, 58a), a następnie jeszcze intensywniej podkreśla przyczynę: „z powodu ich niedowiarstwa” (Mt 13, 58b).

Obecnie przedstawimy ważniejsze zmiany pod względem mariologicznym, dokonane przez Ewangelistę w relacji Mt 13, 53-58 - względem Markowego tekstu źródłowego (6, 1-6). Redaktor pierwszej Ewangelii synoptycznej opisuje wprawdzie reakcję mieszkańców Nazaretu, zresztą tak samo jak i św. Marek, w postawionych kilku kwestiach. Św. Mateusz poczynił to w relacji 13, 54a. b. 56a. b. Jednakże owe wątpliwości częściowo inaczej niż św. Marek $(6,1-6)$ uporządkował oraz sformułował.

Szczególną uwagę zwracają dwie różnice w relacji Mt 13, 53-58 w stosunku

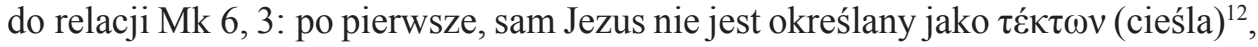
lecz jako: „syn cieśli” ( $\tau \dot{\kappa} \kappa \tau \omega v$ - w znaczeniu: „syn Józefa” - Mt 13, 55); po drugie, dodatek „Syn Maryi” zostaje zastąpiony przez sformułowanie odnoszące się do Maryi, Matki Jezusa: „Czy Jego Matce nie jest na imię Mariam” (Mt 13, 55b) ${ }^{13}$.

Odnosząc się do pierwszej zmiany dokonanej przez św. Mateusza względem Markowej relacji, można by ją sprowadzić do tego, że redaktor pierwszej Ewangelii synoptycznej uważał termin określający wykonywany zawód cieśla - stolarz, jako określenie odnoszące się do Jezusa, za poniżające, oraz nie do pogodzenia, jako

\footnotetext{
${ }^{10}$ Por. Mk 6, $1 \mathrm{~b}$.

${ }^{11}$ Por. Mt 10, 17: wskazuje w tym kontekście na podobne, ale jeszcze bardziej groźnie brzmiące słowa, równocześnie zapowiadając zawarte w mowie misyjnej oskarżenie wysunięte przeciwko Żydom.

${ }^{12}$ Cieśla - w sensie raczej stolarza.

${ }^{13}$ Greckie brzmienie imienia Maryi odpowiada bardziej aramejskiemu Mariam niż hebrajskiemu Miriam; por. Wj 15, 20 według hebr. i LXX.
} 
nieodpowiednie ${ }^{14}$. Można uznać, iż św. Mateusz zamierzał ukazać w swojej relacji ewangelicznej na wyższym poziomie postawioną chrystologię, niźli św. Marek, którego język relacji jest bardziej archaiczny, prosty, mniej składny i poprawny jakościowo pod względem stylu.

Z drugiej strony nie można wykluczyć możliwości, że św. Mateusz nosił się z zamiarem, aby czytelnikom jego Ewangelii, którzy wiedzą o poczęciu (tajemnicy Wcielenia) Jezusa z Ducha Świętego (Mt 1, 18. 20), jeszcze silniej ukazać niezrozumienie Nazarejczyków okazywane wobec osoby Jezusa. W taki oto sposób Ewangelista podkreśliłby także i wyjaśnił, że to nie kto inny, lecz akurat ziomkowie - krajanie Jezusa nie poznali jeszcze tajemnicy Jego Boskiego pochodzenia.

W każdym razie zawarty w relacji tytuł charakteryzujący - prezentujący w Nazarecie Jezusa jako „syna cieśli”, nawiązuje równocześnie do Jego prawnego ojca - ziemskiego opiekuna. Fakt ten jest porównywalny z dodatkową identyfikacją Jezusa, dokonaną przez wymienienie z imienia Jego Matki.

Odnosząc się do drugiej zmiany dokonanej przez św. Mateusza w stosunku do Markowej relacji $(6,1-6)$, należy zauważyć, że jest ona powiązana i odpowiada całkowicie przedstawionemu już w Mt 1,1-17 wizerunkowi Jezusa. W tymże wizerunku istotowo ważne było dla Ewangelisty, ze względu na przeprowadzenie dowodzenia, że Jezus jest prawdziwym Synem Józefa - ponieważ on Go uznał. Tym samym św. Mateusz wykazał pochodzenie z rodu Dawidowego. Poczyniona w relacji Mt 13, 55 wzmianka o Maryi (bezpośrednio po Józefie) ma według zamiaru redakcyjnego Ewangelisty przypominać czytelnikowi, że Maryja została Matką Jezusa - Mesjasza, za sprawą Ducha Świętego ${ }^{15}$.

Według relacji Mt 13, 57c zawierającej logion - odpowiedź Jezusa na lekceważenie, którego doznał wśród swoich współziomków w Nazarecie, Ewangelista opuścił

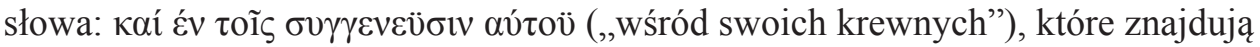
się w relacji Mk 6, 4. Św. Mateusz najwidoczniej czyni to ${ }^{16}$ ze względu na krewnych Jezusa, a zwłaszcza na Maryję, Jego - Mesjasza - Matkę. Ów respekt okazywany dla Maryi, Matki Jezusa - Mesjasza można w sposób logicznie uzasadniony wyjaśnić z perspektywy relacji Mt 1, gdzie była mowa o poczęciu Jezusa przez Maryję za sprawą Ducha (Mt 1, 18. 20). Jest to uzasadniony zabieg redakcyjny perykopy Mt 13,53-58, inaczej byłoby dla czytelnika niezrozumiałe, że Matka, która poczęła Jezusa za sprawą Ducha Świętego, nie miałaby Go czcić.

\section{Mariologiczne znaczenie perykopy Mt 13, 53-58}

Mt 13, 53-58 nie zawiera wyraźnie przedstawionej wzmianki odnośnie do dziewiczego poczęcia. Można uznać, że w relacji Mt 13, 55 jest ono zakładane, ale

\footnotetext{
${ }^{14} \mathrm{~W}$ porównaniu z relacją Markową $(6,1-6)$ i tekstami pozostałymi w drugiej Ewangelii synoptycznej.

${ }^{15}$ Jak to uprzednio opisał Ewangelista w relacji zawartej w Mt 1, 18-25.

${ }^{16}$ Tak samo jak uprzednie opuszczenie relacji z Mk 3, 20n.
} 
domyślnie. W szczególny sposób natomiast zostało w Mt 13, 53-58 wyeksponowane macierzyństwo Maryi, jako Matki Jezusa - Mesjasza. Ma to swoje uzasadnienie w uprzednio wspominanym zamiarze redakcyjnym św. Mateusza, który zamierzał priorytetowo wyeksponować motywy chrystologiczne w swojej Ewangelii, ale równocześnie przedstawić je jako nierozerwalnie zależne i powiązane z tematyką mariologiczną.

Poza tym wypada podsumować, że św. Mateusz w relacji Mt 13, 53-58 odniósł się krytycznie do wcześniejszej (dla niego źródłowej) relacji ewangelicznej według św. Marka, w której pewnego rodzaju skromne, może nieco chybione, zaprezentowanie obrazu Maryi jako Matki Jezusa - Mesjasza, zostało przez autora pierwszej Ewangelii synoptycznej przynajmniej po części pozbawione ostrości, dzięki czemu zyskuje bardziej perfekcyjny, neutralny ton obiektywnego przekazu. Relacja Mt 13, 53-58 uzyskuje pozytywny wydźwięk dzięki odniesieniu jej do zapisu Ewangelii Dziecięctwa Jezusa Chrystusa (Mt 1-2), której wydaje się być konsekwentnym następstwem.

\section{Ogólny obraz Maryi, Matki Jezusa - Mesjasza, według relacji Mt 13, 53-58}

Dokonując kompleksowego podsumowania badań na temat przekazu zamysłu teologicznego Ewangelii według św. Mateusza odnośnie do myśli mariologicznej zawierającej się w relacji pierwszej Ewangelii synoptycznej, należy stwierdzić, iż nie odnajdujemy w niej mariologii w bezpośrednim i wyraźnym sensie. Łatwo wyrobić sobie opinię, że Ewangelista nie okazuje zbyt wielkiego zainteresowania postacią Maryi. Właściwie nie można powiedzieć, by św. Mateusz wyraźnie nakreślił wizerunek - obraz Maryi, Matki Jezusa Mesjasza - ponieważ w swojej relacji nie zawarł rzetelnego opisu Jej postaci. Czytelnik jego Ewangelii nie dowiaduje się niczego o osobistych uczuciach, myślach czy cechach Maryi. Nie dowiaduje się nawet ani nie dostrzega czegokolwiek na temat Jej reakcji na poszczególne wydarzenia zbawcze.

Wypada stwierdzić, że postawa Maryi w relacji ewangelicznej św. Mateusza jest potwierdzeniem dla jego chrystologicznych i historiozbawczych zamysłów redakcyjnych, a w sposób szczególny dla Mt 1-2. Jest ona postacią wielce znaczącą i w sposób niezwykły honorowaną. Dodatkowo należy wskazać, że w odpowiednich miejscach relacji ewangelicznej czy wypowiedziach, przede wszystkim w tych o niepokalanym poczęciu i dziewictwie Maryi, widoczny jest szczególny szacunek, jakim Ją darzono. Jest to świadectwo przekonujące o okazywanym Jej wyjątkowym poważaniu, przynależącym Jej - jako Matce Jezusa - Mesjasza w Kościele archaicznym, jeszcze za czasów ziemskiego życia Ewangelisty.

Mówiąc o mariologii w kontekście tematyki chrystologiczno-historiozbawczej, trzeba zwrócić uwagę, że św. Mateusz zaprezentował w swojej Ewangelii, przez 
Maryję i w Jej osobie, przede wszystkim jedyną w swoim rodzaju misję, jako zadanie postawione przed Nią przez Boga do wykonania, lub jak można również mniemać - Jej niezwykły urząd, którego doświadczyła w pełni zaszczytu okazanego Jej przez samego Boga - Stwórcę.

Maryja w Ewangelii według św. Mateusza została przedstawiona jako: dziewica zapowiadana przez proroka (Mt 1, 23); ta, która poczęła za sprawą Ducha Świętego (Mt 1, 18. 20); ta, która porodziła Syna i staje się tym samym Matką Jezusa - Mesjasza (Mt 1, 16); postacią konieczną w zbawczym planie Bożym.

Jednakże w całym tym kontekście prezentuje się Ona odmiennie od św. Józefa, który okazuje swoje aktywne posłuszeństwo Bogu (Mt 1, 24n; 2, 14. 21n). Maryja prezentuje się w Ewangelii według św. Mateusza jako postać pasywna, bierna z punktu widzenia faktycznego działania względem Boga. Maryja została przedstawiona jako kobieta, która jest catkowicie, i w płeni zaufania, lecz niejako przedmiotowo oddana Bogu w realizacji przewidzianego dopełnienia przez Niego dzieła zbawienia ludzkości. Maryja osobiście w żaden sposób nie ingeruje w bieg wydarzeń, ponieważ wierzy i ufa woli Bożej bez jakiejkolwiek wewnętrznej rezerwy. Maryja pojawia się w pierwszej Ewangelii jako Matka Dziecięcia - Jezusa - Mesjasza (Mt 2, 11. 13n. 20n; 13, 55), jako postać Jemu najbliższa, najściślej z Nim związana. Ma również udział podczas publicznej działalności Jej Syna, udział w tym sensie, że jest świadkiem w spotykającym Jezusa niezrozumieniu (chociażby wśród swoich w Nazarecie). W tym względzie Maryja w Ewangelii według św. Mateusza została zaprezentowana w zapowiedzi - wizji Jej obrazu ewangelicznego jako Mater dolorosa. Jednakże Maryja, jako Matka Jezusa - Mesjasza, ma już udział w należnej i okazywanej Jezusowi czci (Mt 2, 10n) ${ }^{17}$.

\section{Summary}

\section{The Mariological interpretation of the pericope Jesus in Nazareth (Mt 13, 53-58)}

In his article the author shows that the evangelical account of Mt 12, 46-50 as well as the pericope of Mt 13, 54-58 do not bring anything new as far as the Marian motifs are concerned just as it was previously presented in his research on Mt 1 and 2.

Mt 13, 53-58 does not include any clear reference to the virginal conception. One can conclude that it is assumed and understood. In Mt 13, 53-58 it is the motherhood of Mary that is emphasized. She is the Mother of Jesus, the Messiah. Such a treatment of the theme is well grounded in the aforementioned editorial means of St. Matthew who wanted to stress the Christological motifs in his Gospel but also to present them as inseparably connected with and depended on the Mariological theme.

${ }^{17}$ Można stwierdzić, że ze względu na całą chrystologię Ewangelisty św. Mateusza, Maryja równocześnie przez to, że zrodzony z Niej Jezus - Mesjasz jest Synem Bożym, prezentuje się według

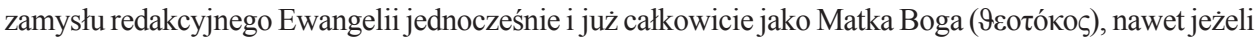
św. Mateusz nigdy Jej wyraźnie tak nie określa, ani też nie przedstawia Jej jako wielce znaczącej Postaci. 
In his article the author asserts that in his account in Mt 13, 53-58 St. Matthew critically refers to the earlier account of St. Mark (which is his source) in which Mark presents Mary, the Mother of Jesus, the Messiah in an inconspicuous, perhaps even ineffective, way. Such a presentation is at least partially smoothed out and therefore the tone of Matthew's presentation of Mary becomes more neutral and veritable. Thus the account of Mt 13,53-58 acquires a new, positive undertone which has already been introduced at the beginning of the narrative in Mt 1-2.

\section{Keywords}

Bible, Gospel, Mariology, Mt 13, 53-58, Matthew Apostle, theology 
